\title{
PENERAPAN MEDIA VIDEO UNTUK MENINGKATKAN MOTIVASI DAN HASIL BELAJAR SISWA PADA MATA DIKLAT TEKNIK BUBUT KELAS XII JURUSAN TEKNIK PEMESINAN SMK N 1 PADANG
}

\section{THE APPLICATION OF VIDEO MEDIA TO INCREASE MOTIVATION AND STUDENT LEARNING OUTCOMES TEKNIK BUBUT SUBJECTS CLASS XII MAJORING MECHANICAL ENGINEERING OF SMK N 1 PADANG}

\author{
Irsan Isral $^{(1)}$, Waskito $^{(2)}$, Syahrul $^{(3)}$, Budi Syahri ${ }^{(4)}$ \\ (1),(2),(3) (4)Jurusan Teknik Mesin, Fakultas Teknik, Universitas Negeri \\ Padang Kampus Air Tawar, Padang 25131, Indonesia \\ irsanisral@yahoo.com \\ waskitosyofia@yahoo.com \\ omchah@gmail.com
}

\begin{abstract}
Abstrak
Berdasarkan survei peneliti, tampak bahwa dalam proses pembelajaran banyak siswa yang pasif, melamun, bermain hand phone, ribut, dan sibuk sendiri dengan kegiatannya. Dari total 29 siswa hanya 10 siswa yang tuntas hasil belajarnya. Penelitian ini bertujuan untuk meningkatkan aktivitas siswa dalam proses pembelajaran melalui penerapan media video yang diharapkan dengan meningkatnya motivasi belajar siswa dapat pula meningkatkan hasil belajar siswa. Penelitian ini merupakan Penelitian Tindakan Kelas (Classroom Action Research), dimana peneliti bertindak sebagai guru yang melakukan tindakan. Penelitian ini dilaksanakan pada bulan November 2016. Penelitian ini terdiri dari dua siklus yang masing-masing terdiri dari dua kali pertemuan. Data dikumpulkan menggunakan lembar observasi untuk melihat perubahan motivasi belajar siswa setiap siklusnya dan untuk pengukur data hasil belajar siswa digunakan lembaran tes. Berdasarkan hasil pengamatan, rata-rata aktivitas siklus I adalah $60,70 \%$ dan pada siklus II adalah 80,24\%. Selain aktivitas belajar siswa, hasil belajar juga mengalami peningkatan ketuntasan secara klasikal. Pada siklus I ketuntasan klasikal adalah 58,62\% dengan 17 siswa tuntas dan pada siklus II adalah 86,21\%dengan 25 siswa tuntas. Dapat disimpulkan bahwa penggunaan media video dapat meningkatkan motivasi dan hasil belajar siswa pada mata diklat teknik bubut di kelas XII TPA SMK N 1 Padang.
\end{abstract}

Kata kunci : Penelitian Tindakan Kelas, Motivasi, Hasil Belajar, Media Video, Teknik Bubut.

\begin{abstract}
According to the survey research, it appears that many students in the learning process is a passive, dreamy, play the hand phone, noisy, and busy themselves with activities. From a total of 29 students only 10 students who completed their learning outcomes. This research aims to increase the motivation of students in the learning process through the implementation of video media are expected with increasing student learning motivation can improve student learning outcomes. This research is a classroom action research, in which researchers act as a teacher to take action. This study was conducted in November 2017. The study consisted of two cycles each consisting of two meetings. Data were collected using observation sheet to see changes in student learning motivation in each cycle and for measuring student learning outcomes data used test sheet. Based on observations, the average activity cycle I is 60,70\% and the second cycle is $80.24 \%$. In addition to student learning motivation, learning outcomes also increased in classical completeness.In the first cycle of classical completeness is $58.62 \%$ with 17 students completed and the second cycle was $86.21 \%$ with 25 students completed. It can be concluded that the use of video media can improve the motivation and student learning outcomes in teknik bubut objects in class XII TPA SMK N 1 Padang.
\end{abstract}

Keyword : Classroom Action Research, Motivation, Learning Outcomes, Media Video, Teknik Bubut. 


\section{Pendahuluan}

Pendidikan berperan dalam mempersiapkan sumber daya manusia yang berkualitas, dalam proses pendidikan terdapat tiga unsur yang sangat menentukan proses pengajaran yaitu, guru, siswa dan kurikulum yang digunakan. Sekolah Menengah Kejuruan (SMK) merupakan suatu lembaga pendidikan yang mencetak tenaga kerja tingkat pemula, menuju tenaga kerja tingkat terampil dalam bidang tertentu. Tujuan utama proses pembelajaran di SMK adalah menuntut siswa untuk berhasil dalam menerapkan kemampuan yang sudah diperolehnya secara teori maupun praktek, sesuai dengan tujuan dari SMK itu sendiri yaitu menghasilkan tenaga kerja menengah yang ahli di bidangnya ditunjang dengan hasil belajar yang memuaskan. Hasil belajar dapat dipandang sebagai salah satu ukuran keberhasilan siswa dalam pendidikan di sekolah dan dijadikan bahan pertimbangan dalam menentukan kemampuan siswa.

Berdasarkan survei yang dilakukan ketika penulis melaksanakan observasi di SMK Negeri 1 Padang tampak bahwa dalam proses pembelajaran siswa kurang aktif dan kurang perhatian terhadap materi ajar yang disajikan oleh guru, banyak siswa yang pasif, melamun, bermain hand phone, ribut, dan sibuk sendiri dengan kegiatannya. Hasil dari aktivitas siswa ini tercermin dalam hasil belajar yang diperolehnya. Pada diklat Teknik Bubut, nilai KKM (Kriteria Ketuntasan Minimum) yang ditentukan di SMK Negeri 1 Padang adalah 80. Hasil belajar siswa kelas XII Teknik Pemesinan pada mata diklat Teknik Bubut kurang memuaskan, seperti ditunjukkan pada tabel berikut ini:
Tabel 1. Persentase Nilai Mid Semester V Siswa

Kelas XII Jurusan Teknik Pemesinan pada Mata Diklat Teknik Bubut di SMK Negeri 1 Padang Tahun Ajaran 2016/2017

\begin{tabular}{|c|c|c|c|}
\hline Kelas & $\begin{array}{c}\text { Siswa } \\
\text { dengan nilai } \\
\text { rata-rata } \\
\geq 80\end{array}$ & $\begin{array}{c}\text { Siswa } \\
\text { dengan nilai } \\
\text { rata-rata } \\
<80\end{array}$ & $\begin{array}{c}\text { Siswa yang } \\
\text { tidak } \\
\text { mengikuti } \\
\text { ujian }\end{array}$ \\
\hline XII TPA & $\begin{array}{c}37,04 \% \\
(10 \text { siswa) }\end{array}$ & $\begin{array}{c}48,15 \% \\
(15 \text { siswa })\end{array}$ & $\begin{array}{c}14,81 \% \\
(4 \text { siswa) }\end{array}$ \\
\hline (29 siswa) & & & \\
\hline
\end{tabular}

Sumber: Guru Mata Diklat Teknik Bubut SMK Negeri 1 Padang

Tabel 1 di atas menunjukkan dari total 29 siswa kelas XII jurusan Teknik Pemesinan pada tahun ajaran 2016/2017, sebanyak 10 siswa $(37,04 \%)$ mencapai hasil belajar teknik bubut yang mencukupi syarat kelulusan. Sementara itu, sebanyak 15 siswa $(48,15 \%)$ belum memenuhi standar kelulusan dan sebanyak 4 siswa lainnya $(14,81 \%)$ tidak mengikuti ujian.

Rendahnya hasil belajar yang diperoleh oleh siswa diduga salah satu faktor penting penyebabnya adalah karena metode mengajar yang digunakan oleh guru. Metode pembelajaran yang digunakan guru pada mata pahat ini hanya berpusat pada guru (teacher centered). Menurut Sudjana (2010:35) strategi pembelajaran ini cepat memacu rasa bosan siswa untuk belajar, sehingga sulit bagi guru untuk dapat melihat perubahan aktivitas siswa dalam belajar dan dapat menyebabkan rendahnya hasil belajar dikarenakan pemanfaatan waktu belajar yang lebih fokus untuk menyelesaikan materi pembelajaran. Menyikapi kondisi tersebut di atas, maka perlu adanya upaya perbaikan kualitas 
pembelajaran pada mata diklat teknik bubut melalui penerapan sebuah model pembelajaran yang dapat merangsang tingkat keaktifan siswa dan memfokuskan perhatiannya pada mata diklat tersebut. Oleh karena itu, diperkirakan penerapan media video dapat digunakan untuk memperbaiki kualitas pembelajaran pada mata diklat teknik bubut Penerapan media video juga dikenal sebagai Pembelajaran Berbasis Masalah (PBM). Menurut Tan dalam Rusman (2010: 229) Pembelajaran Berbasis Masalah merupakan inovasi dalam pembelajaran karena dalam PBM kemampuan berfikir siswa betul-betul dioptimalisasikan melalui proses kerja kelompok atau tim yang sistematis, sehingga siswa dapat memberdayakan, mengasah, menguji, dan mengembangkan kemampuan berpikirnya secara berkesinambungan. Perlu dipahami bahwa hakikat pembelajaran adalah kemauan siswa untuk belajar tidak hanya berdasarkan apa yang diberikan oleh guru saja, seperti yang diungkapkan Ivor K, Davis (2000) dalam Rusman (2010: 229).

\section{Metode Penelitian}

Jenis penelitian yang penulis lakukan adalah penelitian tindakan kelas (PTK) atau dikenal sebagai classroom action research (CAR). Penelitian ini terdiri dari dua siklus. Pada setiap siklus terdapat empat tahap dalam pelaksanaannya, yaitu perencanaan, tindakan, observasi dan refleksi. Penelitian ini dilaksanakan sebanyak dua siklus selama 4 minggu, yang mana dalam 1 siklus terdiri atas 2 kali pertemuan dan dalam 2 minggu 2 kali pertemuan tatap muka.

Penelitian ini dilakukan untuk meningkatkan motivasi dan hasil belajar siswa kelas XII TPA pada mata diklat teknik bubut melalui penerapan media video. Penelitian dilaksanakan dengan melakukan pengamatan dan penilaian bersama kolaborator terhadap aktivitas siswa dalam belajar pada tahapan pembelajaran untuk melihat peningkatan motivasi dan untuk melihat hasil belajar siswa setelah diterapkannya media video ini, dilakukan tes hasil belajar di setiap akhir siklus yang berbentuk tes objektif yang terlebih dahulu terhadap soal-soal tersebut dilakukan analisis butir soal untuk mengetahui taraf kesukaran dan daya pembeda soal serta mencari nilai validitas butir dan reliabilitas soal.

Aspek pengamatan motivasi siswa yang yang akan digunakan pada lembar pengamatan adalah sebagai berikut:

Tabel 2. Aspek Pengamatan Motivasi Siswa untuk Lembar Pengamatan

\begin{tabular}{|c|c|c|c|}
\hline No & Indikator & $\begin{array}{c}\text { Sub Indikator } \\
\text { (Aspek Pengamatan) }\end{array}$ & $\begin{array}{l}\text { No. } \\
\text { Item }\end{array}$ \\
\hline \multirow[t]{2}{*}{1.} & \multirow{2}{*}{$\begin{array}{l}\text { Siswa } \\
\text { mengikuti } \\
\text { pembelajaran } \\
\text { dengan baik }\end{array}$} & $\begin{array}{l}\text { Siswa aktif } \\
\text { memperhatikan } \\
\text { penjelasan guru }\end{array}$ & 1 \\
\hline & & $\begin{array}{l}\text { Siswa aktif bertanya } \\
\text { kepada guru atau teman } \\
\text { mengenai materi yang } \\
\text { belum dipahami }\end{array}$ & 2 \\
\hline \multirow[t]{2}{*}{2.} & \multirow{2}{*}{$\begin{array}{l}\text { Siswa } \\
\text { mengidentifikasi } \\
\text { masalah yang } \\
\text { diberikan oleh } \\
\text { guru }\end{array}$} & $\begin{array}{l}\text { Siswa aktif membaca buku } \\
\text { untuk mencari sumber jawaban } \\
\text { yang benar dalam mengerjakan } \\
\text { tugas di kelas }\end{array}$ & 3 \\
\hline & & $\begin{array}{l}\text { Siswa dapat bekerjasama } \\
\text { dengan teman sebangku }\end{array}$ & 4 \\
\hline 3. & $\begin{array}{l}\text { Siswa mencatat } \\
\text { konsep-konsep } \\
\text { yang digunakan } \\
\text { dalam pemecahan } \\
\text { masalah }\end{array}$ & $\begin{array}{l}\text { Siswa membuat laporan } \\
\text { pemecahan masalah hasil } \\
\text { diskusinya }\end{array}$ & 5 \\
\hline \multirow[t]{2}{*}{4.} & \multirow{2}{*}{$\begin{array}{l}\text { Siswa mencari } \\
\text { berbagai } \\
\text { informasi yang } \\
\text { diperlukan dalam } \\
\text { pemecahan } \\
\text { masalah }\end{array}$} & $\begin{array}{l}\text { Siswa tidak mudah putus asa } \\
\text { dalam mengerjakan sesuatu di } \\
\text { kelas }\end{array}$ & 6 \\
\hline & & $\begin{array}{l}\text { Siswa bertanya jika ada } \\
\text { yang tidak dimengerti } \\
\text { dalam mengerjakan } \\
\text { tugas }\end{array}$ & 7 \\
\hline 5. & $\begin{array}{l}\text { Siswa menunjukkan } \\
\text { minat } \\
\text { terhadap } \\
\text { bermacam-macam } \\
\text { masalah }\end{array}$ & $\begin{array}{l}\text { Siswa menunjukkan } \\
\text { kepedulian } \\
\text { terhadap teman-temannya } \\
\text { yang belum berhasil }\end{array}$ & 8 \\
\hline \multirow[t]{3}{*}{6.} & \multirow{3}{*}{$\begin{array}{l}\text { Siswa aktif } \\
\text { menanggapi hasil } \\
\text { pemecahan } \\
\text { masalah dengan } \\
\text { tetap menghargai } \\
\text { dan menerima } \\
\text { pendapat orang } \\
\text { lain }\end{array}$} & $\begin{array}{l}\text { Siswa percaya diri dalam } \\
\text { melakukan sesuatu di kelas } \\
\text { saat pelajaran }\end{array}$ & 9 \\
\hline & & $\begin{array}{l}\text { Siswa berbicara dengan } \\
\text { sopan ketika mengutarakan } \\
\text { pendapat atau pertanyaannya }\end{array}$ & 10 \\
\hline & & $\begin{array}{l}\text { Siswa mampu } \\
\text { mempertahankan } \\
\text { pendapatnya beserta } \\
\text { alasannya di hadapan } \\
\text { teman yang lainnya }\end{array}$ & 11 \\
\hline 7. & $\begin{array}{l}\text { Siswa mencatat } \\
\text { hasil pemecahan } \\
\text { masalah yang } \\
\text { telah disimpulkan } \\
\text { bersama }\end{array}$ & $\begin{array}{l}\text { Siswa mencatat kesimpulan } \\
\text { hasil pemecahan masalah } \\
\text { pada buku catatan }\end{array}$ & 12 \\
\hline
\end{tabular}


Data isian lembar pengamatan motivasi belajar siswa akan dianalisis dengan cara kuantitatif dalam bentuk persentase. Untuk melihat persentase aktivitas siswa pertahaınnya digunakan sebagai berikut:

$$
\mathrm{P}=\frac{\sum X}{\sum Y} x 10 \mathrm{C} \%
$$

Dengan keterangan:

$\mathrm{P} \quad$ : Persentase aktivitas yang diamati setiap pertemuan

$\sum X \quad$ : Jumlah skor aktivitas siswa

$\sum \mathrm{Y} \quad$ : Jumlah skor maksimal aktivitas

Selanjutnya dalam keterangan persentase yang diperoleh sebagai interpretasi aktivitas belajar penilaian akan berpedoman pada tabel kategori oleh Memes (2001:36) berikut:

Tabel 3. Klasifikasi Penilaian Aktivitas Siswa

\begin{tabular}{|c|c|c|}
\hline No & Interval & Kategori \\
\hline 1 & $\geq 75,6 \%$ & AKTIF \\
\hline 2 & $59,6 \%-75,5 \%$ & CUKUP AKTIF \\
\hline 3 & $\leq 59,5 \%$ & KURANG AKTIF \\
\hline
\end{tabular}

Sementara itu, untuk memperoleh persentase penilaian hasil belajar digunakan rumus sebagai berikut:

1. Ketuntasan individu

$$
\mathrm{NI}=\frac{\mathrm{T}}{\mathrm{SM}} \times 100 \%
$$

Dengan keterangan:

NI : ketuntasan belajar secara individu

$\mathrm{T} \quad$ : Skor yang diperoleh siswa

SM : Skor maksimum dari tes

Ketuntasan belajar individu ini mengacu kepada ketentuan yang telah ditetapkan dalam kurikulum SMK Negeri 1 Padang yaitu sebesar 80.

2. Ketuntasan Klasikal

Dengan keterangan:

$$
\mathrm{NT}=\frac{\mathrm{ST}}{\mathrm{n}} \times 100 \%
$$

NT : Ketuntasan belajar secara klasikal

ST : Jumlah siswa yang tuntas belajar

$\mathrm{n} \quad$ : Jumlah seluruh siswa dalam satu kelas
Ketuntasan klasikal tercapai apabila nilai ketuntasan klasikal kelas telah mencapai persentase nilai $80 \%$. Penelitian ini dapat dikatakan berhasil dan bisa dihentikan apabila sudah mencapai indikator yang diinginkan. Indikator keberhasilan pelaksanaan tindakan perbaikan kualitas pembelajaran dapat ditetapkan oleh guru yang dalam hal ini adalah peneliti sendiri sesuai kemampuan siswa dan tingkat perbaikan yang ingin dicapai. Kriteria keberhasilan dalam peningkatan kualitas pembelajaran pada penelitian ini melalui penerapan media video yaitu: 1. Motivasi belajar:

a. Pada siklus I, aktivitas belajar siswa mencapai persentase sebesar $60 \%$.

b. Pada siklus II, aktivitas belajar siswa mencapai persentase sebesar $80 \%$.

2. Hasil belajar:

a. Pada siklus I, hasil belajar siswa mencapai persentase sebesar 50\%.

b. Pada siklus II, hasil belajar siswa mencapai persentase sebesar $80 \%$.

\section{Hasil dan Pembahasan}

Penelitian ini dilaksanakan sebanyak 2 siklus yang terdiri dari 2 kali pertemuan masing-masing siklusnya. Berdasarkan tindakan yang telah dilakukan pada siklus I diketahui bahwa aktivitas dan hasil belajar siswa telah mencapai indikator keberhasilan tindakan pada siklus I. Dimana keaktifan siswa diambil melalui lembar pengamatan motivasi dengan persentase nilai sebesar $60,70 \%$ dan nilai ketuntasan klasikal kelas yang diambil berdasarkan tes pada akhir siklus I sebesar $58,62 \%$.

Kelemahan yang ditemukan pada siklus I terdapat pada pertemuan 1 dimana proses pembelajaran berlangsung gaduh dan berlangsung cukup lama yaitu selama 15 menit. Hal ini disebabkan karena persiapan media pembelajaran bukan disiapkan sebelumnya oleh guru selaku peneliti sehingga menyita waktu pembelajaran yang menyebabkan tidak dapatnya dilaksanakan presentasi pada pertemuan 1. Presentasi yang dilakukan pada siklus I menyediakan waktu yang cukup singkat karena bagi setiap masing-masing siswa banyak yang tidak melakukan tanya jawab karena siswa banyak yang belum paham dengan materi yang diberikan oleh guru sehingga proses pembelajaran jadi tidak efektif. 
Selain itu, kehadiran 2 siswa baru pada tahap presentasi menyebabkan belum mantapnya pemahaman siswa pada materi ajar di siklus I ini sehingga keaktifan siswa tergolong dalam kategori kurang aktif dan hasil tes belajar siswapun belum memenuhi KKM yang ditetapkan sebesar 80.

Memperbaiki proses pembelajaran guna meningkatkan motivasi siswa pada siklus berikutnya dan meningkatkan motivasi pada aspek pengamatan terutama aspek yang tergolong dalam kategori kurang aktif agar dapat mencapai indikator keberhasilan pada siklus berikutnya, maka hasil tes belajar siswa di akhir siklus I digunakan untuk membagi siswa menjadi beberapa kelompok secara heterogen agar tidak kembali menyita waktu diskusi dan presentasi.

Sementara itu, tindakan yang dilakukan pada siklus II telah dapat meningkatkan motivasi belajar dan hasil belajar siswa pada mata diklat teknik bubut. Hal ini dibuktikan dengan peningkatan motivasi siswa menjadi $80,24 \%$ dan hasil ketuntasan belajar siswa secara klasikal meningkat menjadi $86,21 \%$.

Berikut ini merupakan pembahasan atau analisis terhadap tindakan pembelajaran Menggunakan media video antara lain:

A. Peningkatan Motivasi Siswa pada Mata Diklat Teknik Bubut menggunakan Media Video.

Dalam pelaksanaan pembelajaran siklus I didapatkan rata-rata motivasi siswa dalam kategori cukup aktif yang kemudian meningkat pada siklus II menjadi kategori aktif. Dari siklus I ke siklus II, siswa terlihat lebih aktif dalam proses pembelajaran yang diberikan. Disebabkan karena guru telah memberikan video-video pembelajaran yang menarik perhatian siswa, sehingga dapat meningkatnya motivasi siswa.

Bila siswa tidak mengerti dengan materi, siswa mulai berani bertanya pada guru dan menanggapi pertanyaan yang ada dengan cara yang semakin baik untuk menemukan hasil pemecahan masalah. Terlihat siswa mulai dapat bekerja sama dalam proses diskusi dan berani tampil mempresentasikan hasil diskusinya.

Hasil pengamatan yang menunjukkan peningkatan aktivitas siswa dalam proses belajar dari siklus I ke siklus II tertera pada tabel berikut ini:
Tabel 4. Persentase Peningkatan Keaktifan SiswaTiap Aspek Pengamatan dari Siklus I ke Siklus II

\begin{tabular}{|c|c|c|c|c|}
\hline \multirow{2}{*}{ No } & \multirow{2}{*}{ Aspek Pengamatan } & \multicolumn{3}{|c|}{ Persentase $(\%)$} \\
\hline & & $\begin{array}{c}\text { Siklus } \\
\text { I }\end{array}$ & $\begin{array}{c}\text { Siklus } \\
\text { II }\end{array}$ & Peningkatan \\
\hline 1. & $\begin{array}{l}\text { Siswa aktif } \\
\text { memperhatikan } \\
\text { penjelasan guru dalam } \\
\text { kegiatan pembelajaran }\end{array}$ & 54,31 & 65,51 & 11,2 \\
\hline 2. & $\begin{array}{l}\text { Siswa aktif bertanya } \\
\text { kepada guru atau } \\
\text { teman mengenai materi } \\
\text { yang belum dipahami }\end{array}$ & 60,34 & 86,20 & 25,86 \\
\hline 3. & $\begin{array}{l}\text { Siswa aktif membaca } \\
\text { buku untuk mencari } \\
\text { sumber jawaban yang } \\
\text { benar dalam } \\
\text { mengerjakan tugas di } \\
\text { kelas }\end{array}$ & 68,10 & 84,48 & 16,38 \\
\hline 4. & $\begin{array}{l}\text { Siswa dapat } \\
\text { bekerjasama dengan } \\
\text { teman sebangku }\end{array}$ & 52,59 & 85,34 & 32,75 \\
\hline 5. & $\begin{array}{l}\text { Siswamembuat laporan } \\
\text { pemecahan masalah } \\
\text { hasil diskusinya }\end{array}$ & 76,72 & 84,48 & 7,76 \\
\hline 6. & $\begin{array}{l}\text { Siswa tidak mudah } \\
\text { putus asa dalam } \\
\text { mengerjakan } \\
\text { sesuatu di kelas }\end{array}$ & 60,34 & 78,45 & 1,11 \\
\hline 7. & $\begin{array}{l}\text { Siswa bertanya } \\
\text { jika ada yang } \\
\text { tidak dimengerti } \\
\text { dalam } \\
\text { mengerjakan } \\
\text { tugas }\end{array}$ & 60,34 & 77,59 & 17,25 \\
\hline 8. & $\begin{array}{l}\text { Siswa menunjukkan } \\
\text { kepedulian } \\
\text { terhadap teman- } \\
\text { temannya yang } \\
\text { belum berhasil }\end{array}$ & 59,48 & 83,62 & 24,14 \\
\hline 9. & $\begin{array}{l}\text { Siswa percaya diri } \\
\text { dalam melakukan } \\
\text { sesuatu di kelas saat } \\
\text { pelajaran }\end{array}$ & 43,1 & 74,14 & 31,04 \\
\hline 10. & $\begin{array}{l}\text { Siswa berbicara } \\
\text { dengan sopan ketika } \\
\text { mengutarakan } \\
\text { pendapat atau } \\
\text { pertanyaannya }\end{array}$ & 50,86 & 78,45 & 27,59 \\
\hline 11. & $\begin{array}{l}\text { Siswa mampu } \\
\text { mempertahankan } \\
\text { pendapatnya beserta } \\
\text { alasannya di hadapan } \\
\text { teman yang lainnya }\end{array}$ & 65,52 & 84,48 & 18,96 \\
\hline 12. & $\begin{array}{l}\text { Siswa mencatat } \\
\text { kesimpulan hasil } \\
\text { pemecahan masalah } \\
\text { pada buku catatan }\end{array}$ & 76,72 & 80,17 & 3,45 \\
\hline $\begin{array}{l}\text { Pers } \\
\text { Aspe }\end{array}$ & $\begin{array}{l}\text { ntase Rata-rata Tiap } \\
\text { x Pengamatan }(\%)\end{array}$ & 60,70 & 80,24 & 19,54 \\
\hline
\end{tabular}


Tabel 4 menunjukkan persentase tiap aspek pengamatan mengalami peningkatan sesuai dengan yang diharapkan. Hasil perhitungan siklus II juga menunjukkan rata-rata aktivitas telah memenuhi indikator keberhasilan $80 \%$.

Berdasarkan penelitian yang telah dilakukan, dapat disimpulkan bahwa penggunaan media video mampu meningkatkan motivasi siswa. Peningkatan motivasi siswa dalam belajar ini dibuktikan dengan peningkatan keaktifan siswa dari siklus I ke siklus II yang telah mencapai indikator keberhasilan tindakan yang ditentukan seperti tertera pada tabel berikut:

Tabel 5 Ketercapaian Keberhasilan Tindakan Penelitian untuk Aktivitas Belajar Siswa

\begin{tabular}{|c|c|c|c|c|}
\hline No & Siklus & $\begin{array}{c}\text { Indikator } \\
\text { Keberhasilan } \\
\text { Tindakan } \\
(\%)\end{array}$ & $\begin{array}{c}\text { Hasil } \\
\text { Penelitian } \\
(\%)\end{array}$ & $\begin{array}{c}\text { Keterangan } \\
\text { Keberhasilan } \\
\text { Tindakan }\end{array}$ \\
\hline 1 & I & 60 & 60,70 & BERHASIL \\
\hline 2 & II & 80 & 80,24 & BERHASIL \\
\hline
\end{tabular}

Berdasarkan tabel 5 diketahui bahwa indikator keberhasilan untuk setiap siklusnya telah tercapai yang menandakan bahwa tindakan penerapan media video pada penelitian ini dapat meningkatkan motivasi belajar siswa kelas XII TPA di SMK Negeri 1 Padang pada mata diklat teknik bubut.

B. Peningkatan Hasil Belajar Siswa pada Mata Diklat Teknik Bubut dengan menggunakan Media Video.

Data yang telah diperoleh berdasarkan hasil penelitian, diketahui bahwa terjadi peningkatan persentase jumlah siswa yang memperoleh nilai mencapai KKM (kriteria ketuntasan minimum) yaitu 80. Dari total 29 siswa, pada siklus I sebanyak 17 siswa dinyatakan tuntas dalam belajar dengan nilai mencapai KKM dan pada siklus II terjadi peningkatan siswa yang tuntas belajar menjadi 25 orang, sementara itu 4 orang siswa yang mendapatkan nilai dibawah KKM dalam penelitian ini dianggap tidak tuntas. Berdasarkan penelitian yang telah dilakukan, dapat disimpulkan bahwa penggunaan media video mampu meningkatkan hasil belajar siswa. Peningkatan hasil belajar ini, dibuktikan dengan peningkatan ketuntasan klasikaldari siklus I ke siklus II yang telah mencapai indikator keberhasilan tindakan yang ditentukan seperti tertera pada table berikut:
Tabel 6. Ketercapaian Keberhasilan Tindakan Penelitian untuk Hasil Belajar Siswa

\begin{tabular}{|c|c|c|c|c|}
\hline No & Siklus & $\begin{array}{c}\text { Indikator } \\
\text { Keberhasilan } \\
\text { Tindakan } \\
(\%)\end{array}$ & $\begin{array}{c}\text { Hasil } \\
\text { Penelitian } \\
(\%)\end{array}$ & $\begin{array}{c}\text { Keterangan } \\
\text { Keberhasilan } \\
\text { Tindakan }\end{array}$ \\
\hline 1 & I & 50 & 58,62 & BERHASIL \\
\hline 2 & II & 80 & 86,21 & BERHASIL \\
\hline
\end{tabular}

Berdasarkan tabel 6 keberhasilan setiap siklusnya telah tercapai menandakan bahwa penerapan media video pada penelitian ini dapat meningkatkan hasil belajar siswa kelas XII di SMK Negeri 1 Padang.

\section{Kesimpulan}

Berdasarkan hasil analisis data yang diperoleh dalam penelitian ini dapat ditarik kesimpulan sebagai berikut:

1. Penerapan media video dapat meningkatkan motivasi belajar siswa. Peningkatan motivasi ini dibuktikan dari peningkatan motivasi belajar siswa dari siklus I sebesar $60,70 \%$ dengan kategori cukup aktif menjadi $80,24 \%$ pada siklus II dengan kategori aktif.

2. Penerapan media video dapat meningkatkan hasil belajar siswa. Peningkatan hasil belajar ini dibuktikan dari peningkatan ketuntasan klasikal yang sebelumnya pada siklus I sebesar 58,62\% dengan 17 siswa yang tuntas meningkat dengan baik pada siklus II menjadi $86,21 \%$ dengan 25 siswa yang tuntas dari total 29 siswa.

\section{Referensi}

Rusman. 2010. Model-Model Pembelajaran. Jakarta: PT. Raja Grafindo Persada.

Sudjana. 2010. Metode dan Teknik Pembelajaran Partisipatif. Bandung: Falah.

W, Memes. 2001. "Perbaikan Pembelajaran Kalor di SLTP". Jurnal Pendidikan dan Pengajaran FKIP Negeri Singaraja. Departemen Pendidikan Nasional Republik Indonesia. 35.

Anas Sudijono. 2011. Pengantar Evaluasi Pendidikan. Jakarta: PT. Raja Grafindo Persada.

Azhar Arsyad. 2004. Media Pembelajaran. Jakarta : PT. Raja Grafindo Persada 
